\title{
LA ABUSIVIDAD DE LAS CLÁUSULAS DE VENCIMIENTO ANTICIPADO EN PRÉSTAMOS HIPOTECARIOS*
}

\section{THE UNFAIRNESS OF MORTGAGE ACCELERATION CLAUSES}

Alicia Agüero Ortiz

Trabajo recibido el 30 de noviembre de 2017 y aprobado el 26 de agosto de 2018

\section{RESUMen}

Existe gran discrepancia en España respecto a la abusividad de las cláusulas que permiten vencer anticipadamente el préstamo por impago de una sola cuota, tal y como permitía nuestra legislación procesal, incluso cuando el acreedor hubiera esperado al incumplimiento de más cuotas para ejercer este derecho. EI TJUE declaró que la evaluación de abusividad debe realizarse sobre la dicción literal de la cláusula, con independencia de la actitud correctora posterior del acreedor. Asimismo, comprendió que la cláusula no está excluida del ámbito de aplicación de la Directiva 93/13/CEE, aunque en base a un argumento erróneo. Con todo, no ha resuelto las cuestiones más controvertidas, a saber, si la abusividad de la cláusula cierra la puerta al proceso de ejecución hipotecaria, y si cabe declarar la abusividad parcial de la cláusula de vencimiento anticipado.

Palabras clave: Directiva 93/13/CEE; Cláusulas abusivas; Contratos de préstamo hipotecario; Procedimiento de ejecución de un bien hipotecado; Cláusulas de vencimiento anticipado.

\begin{abstract}
There is great controversy in Spain concerning the unfairness of terms that allow creditors to accelerate the maturity of the loan in case of the nonpayment of one installment, as Spanish procedural Law stated, even if the accreditor had accelerated the maturity after the nonpayment of more installments. The ECJ ruled that the unfairness assessment should be made according to the literalness of the term, regardless of creditor's subsequent corrective attitude. Moreover, the ECJ stated that these terms were subject to the provisions of Directive 93/13/EEC, albeit the ECJ got to that conclusion on the basis of an incorrect argument. However, the ECJ did not resolve the most controversial issues on the subject, namely, whether the term's unfairness should impede the foreclosure; and whether it is possible to declare the partial unfairness of the accelerated maturity term.
\end{abstract}

Keywords: Directive 93/13/EEC; Unfair terms; Mortgage contracts; Foreclosure; Acceleration clause.

\footnotetext{
* Alicia Agüero Ortiz. Investigadora y docente predoctoral FPU, Departamento de Derecho Civil e Internacional Privado y Cen-
} tro de Estudios de Consumo (CESCO), Universidad de Castilla-La Mancha, Toledo, España. Correo de contacto, a.aortiz@uclm.es. 


\section{INTRODUCCIÓN}

A raíz de la crisis económica global, España ha experimentado una verdadera revolución en materia de cláusulas abusivas, especialmente en el sector hipotecario. Las numerosas ejecuciones hipotecarias que privaban a los consumidores de sus viviendas provocaron una reacción judicial, guiada por la justicia material, de forma tal que comenzó a cuestionarse la validez instituciones y cláusulas que nunca antes habían sido cuestionadas. La cláusula paradigmática en este sentido es la cláusula de vencimiento anticipado, que permite vencer anticipadamente el préstamo hipotecario si el deudor impagara cualquier parte de capital o intereses del préstamo, autorizado al acreedor hipotecario a iniciar el proceso ejecutivo. La validez de esta cláusula nunca había sido puesta en tela de juicio pues reproducía el contenido del art. 693 de nuestra Ley de Enjuiciamiento Civil. Sin embargo, en 2013 el Tribunal de Justicia de la Unión Europea declaró que solo sería válido vencer anticipadamente el préstamo en caso de incumplimiento grave y esencial. Este pronunciamiento provocó la reforma del citado precepto, que a partir de mayo de 2013 exigiría el incumplimiento de una cantidad equivalente a tres mensualidades del préstamo hipotecario para poder declarar vencido anticipadamente el préstamo hipotecario y acceder al proceso de ejecución hipotecaria.

La reforma del precepto, lejos de aportar seguridad jurídica provocó grandes controversias judiciales. En primer lugar, debía esclarecerse si las cláusulas que reprodujeran un precepto legal estaban sujetas al control de abusividad, habida cuenta del principio de presunción de adecuación de la normativa nacional previsto en el art. 1.2 Directiva 93/13/CEE sobre cláusulas abusivas. En segundo lugar, surgían dudas sobre si la regla de las tres mensualidades debía ser tomada como criterio de abusividad. En tercer lugar, dado que los acreedores comenzaron a esperar a la acumulación de varios incumplimientos para vencer anticipadamente los préstamos, debía aclararse si la abusividad de la cláusula debía efectuarse sobre su dicción literal o si debía tomarse en consideración la actitud correctora del acreedor. En cuarto lugar, algunos tribunales se cuestionaron si cabría una nulidad parcial de la cláusula de vencimiento anticipado, de forma que hubiera una parte de ella abusiva (v.gr. vencer anticipadamente por el incumplimiento de una cuota), pero otra no abusiva ( $v$.gr. vencer anticipadamente por el incumplimiento de ocho cuotas). Finalmente, surgieron discrepancias respecto a los efectos de la declaración de abusividad de la cláusula de vencimiento anticipado, en concreto, respecto a si su nulidad debía comportar el cierre de las puertas al proceso de ejecución hipotecaria.

Adicionalmente, el gobierno español está trabajando en un nuevo Anteproyecto de Ley de Créditos Inmobiliarios, cuyo artículo 15 introduce una nueva norma imperativa de vencimiento anticipado, que pretende reestablecer la inseguridad jurídica existente en la materia.

\section{Las Cláusulas de vencimiento anticipado en el Ordenamiento jurídico español}

El Código Civil español (en adelante, "CC") define en su art. 1740 el contrato de préstamo como aquel en el que "una de las partes entrega a la otra, o alguna cosa no fungible para que use de ella por cierto tiempo y se la devuelva, en cuyo caso se llama comodato, o dinero u otra cosa fungible, con condición de devolver otro tanto de la misma especie y calidad, en cuyo caso conserva simplemente el nombre de préstamo". Los préstamos hipotecarios no son más que préstamos de dinero o cosa fungible en los que se concede al acreedor un derecho real de garantía sobre un bien inmueble, como puede ser la vivienda habitual. De esta forma, el deudor garantiza el pago mediante un derecho real sobre un inmueble, derecho real que faculta al

AGÜERO ORTIZ, Alicia. La abusividad de las cláusulas de vencimiento anticipado en préstamos hipotecario. Revista Justicia y Derecho, Santiago, v. 1, n 1, 2018 
prestamista a ejecutar dicha garantía para recobrar las cantidades prestadas en caso de incumplimiento del deudor.

La obligación principal de todo prestatario es la devolución del importe prestado con los intereses oportunos, en caso de haberse pactado (arts. 1753 y 1754 CC en relación con el art. 1170 CC). El momento en que el prestatario deba efectuar su entrega será el estipulado en el contrato, en virtud del principio de autonomía de la voluntad (art. 1255 CC).

Por lo tanto, podemos observar como el "vencimiento" no es más que la fecha o plazo en que el prestatario debe cumplir con su obligación de devolución de entrega del capital prestado y los intereses devengados y, consecuentemente, la fecha en que estos importes pueden ser exigidos por el acreedor. Este plazo o vencimiento puede ser único, en caso de pactarse la devolución de la totalidad del capital e intereses en una única fecha; o puede ser fraccionado o periódico, en caso de que la devolución se prevea en distintas fechas. Los préstamos hipotecarios son, típicamente, préstamos a largo plazo con vencimientos fraccionados o periódicos fijándose este plazo en meses, de forma que la amortización (o devolución del importe prestado) se dividirá en predeterminadas cuotas mensuales.

Así las cosas, incumplida la obligación de reembolso de alguna de las cuotas en la fecha debida, el acreedor podrá exigir el pago de la misma (con los intereses de demora que se hubieran pactado), pero no de las cuotas futuras que aún no se hubieran impagado, puesto que no se ha producido su vencimiento, es decir, no ha nacido la obligación de pago. Por lo mismo, en principio, el deudor no podría amortizar más capital que el pactado para cada vencimiento mediante pagos anticipados, pues se compelería al acreedor a ver disminuidos los intereses a percibir por el préstamo. Pues bien, ante las circunstancias anteriores se han creado las conocidas cláusulas de vencimiento anticipado o aceleración y de amortización anticipada, respectivamente.

En esencia, la finalidad de las cláusulas de vencimiento anticipado es poner fin al aplazamiento pactado ${ }^{1}$ ante determinadas circunstancias que pongan el riesgo el recobro del préstamo por el acreedor. Es decir, privar al prestatario del beneficio de la devolución aplazada del préstamo en los diversos vencimientos futuros, declarando la totalidad de la deuda vencida -antes del plazo pactado- estando así el deudor obligado a la entrega de todo el capital e intereses aplicables en dicho momento.

Con todo, el vencimiento anticipado o aceleración de las obligaciones no es una figura creada ex novo por los prestamistas, sino que se trata de una sanción para el obligado que incumpliere sus obligaciones ya prevista en el art. 1129 CC, el cual regula las cuatro causas legales de vencimiento anticipado de las obligaciones a plazo. En particular, establece el citado artículo que "[P]erderá el deudor todo derecho a utilizar el plazo: (i) cuando, después de contraída la obligación, resulte insolvente, salvo que garantice la deuda; (ii) cuando no otorgue al acreedor las garantías a que estuviese comprometido; o (iii) cuando por actos propios hubiese disminuido aquellas garantías después de establecidas, y cuando por caso fortuito desaparecieran, a menos que sean inmediatamente sustituidas por otras nuevas e igualmente seguras".

Lo que sí ha hecho la autonomía de la voluntad de los prestamistas es crear cláusulas de vencimiento anticipado para supuestos específicos no previstos en el anterior precepto. Así pues, existen cláusulas de vencimiento anticipado por diversos motivos como la falta de inscripción de la escritura de hipoteca en el Registro de la Propiedad por causa imputable al prestatario; por incendio o disminución del valor de la finca hipotecada sin aportarse garantías adicionales; por incumplimiento de la obligación de no arrendar sin consentimiento del acreedor hipotecario; por no destinar el importe del préstamo a la finalidad establecida, etc. En este artículo nos centraremos la cláusula de vencimiento anticipado por falta de pago de

1 PUYALTO (2007).

AGÜERO ORTIZ, Alicia. La abusividad de las cláusulas de vencimiento anticipado en préstamos hipotecario. Revista Justicia y Derecho, Santiago, v. 1, n 1, 2018 
cualquier parte de capital del préstamo o de sus intereses en sus vencimientos.

La posibilidad de vencer anticipadamente el préstamo hipotecario por impago de alguna parte de capital o de los intereses ha encontrado amparo legislativo desde los inicios de la regulación hipotecaria española, como requisito de acceso a los procesos hipotecarios. Así, el art. 135 Decreto de 8 de febrero de 1946, por el que se aprueba la nueva redacción oficial de la Ley Hipotecaria (en adelante, "LH")2, permitía el acceso al antiguo procedimiento judicial sumario en caso de que "deje de pagarse una parte del capital del crédito o los intereses, cuyo pago deba hacerse en plazos diferentes, si venciere alguno de ellos sin cumplir el deudor su obligación, y siempre que tal estipulación conste inscrita en el Registro"3. La promulgación de la Ley 1/2000, de 7 de enero, de Enjuiciamiento Civil (en adelante, "LEC"), que acabó con el antiguo procedimiento judicial sumario previsto en el art. $131 \mathrm{LH}$ creando el proceso ejecutivo sobre bienes hipotecados y pignorados, mantuvo aquella previsión en su artículo 693.1 intitulado "[R]eclamación limitada a parte del capital o de los intereses cuyo pago deba hacerse en plazos diferentes. Vencimiento anticipado de deudas a plazos" sosteniendo que" [L]o dispuesto en este capítulo será aplicable al caso en que deje de pagarse una parte del capital del crédito o los intereses, cuyo pago deba hacerse en plazos diferentes, si venciere alguno de ellos sin cumplir el deudor su obligación, y siempre que tal estipulación conste inscrita en el Registro", añadiendo su apartado 2 que "[P]odrá reclamarse la totalidad de lo adeudado por capital y por intereses si se hubiese convenido el vencimiento total en caso de falta de pago de alguno de los plazos diferentes y este convenio constase inscrito en el Registro".

Por consiguiente, el citado precepto permitía declarar el vencimiento anticipado por el impago de "una parte de capital o intereses". Adicionalmente, la posibilidad de acelerar o vencer anticipadamente el préstamo hipotecario en caso de impago parcial exigía la inclusión de una cláusula a este respecto en la escritura de dicho préstamo y su inscripción registral, por lo que todo prestamista procedió a la inclusión de estas cláusulas en sus contratos reproduciendo, generalmente, el contenido del artículo mencionado.

Esta redacción se mantuvo inalterada hasta la modificación de la LEC operada por la Ley 1/2013 de 14 de mayo, de medidas para reforzar la protección a los deudores hipotecarios, reestructuración de deuda y alquiler social (en vigor desde el 15 de mayo de 2013), motivada por la STJUE de 14 de marzo de 2013, como estudiaremos más adelante. La nueva redacción del art. 693.1 LEC exigía ahora el impago de al menos tres plazos mensuales (o el número de cuotas equivalente) para poder vencer anticipadamente el préstamo y acceder al proceso ejecutivo hipotecario.

La validez de las cláusulas de aceleración o vencimiento anticipado por incumplimiento de una sola cuota del préstamo (incumplimiento amparado por el concepto "cualquier parte de capital" del art. 693 LEC) fue reiterada de antiguo por el Tribunal Supremo español (en adelante, "TS") 4 , siempre que "nos encontremos ante una verdadera y manifiesta dejación de las obligaciones de carácter esencial contraídas, como puede ser, ciertamente, el incumplimiento por el prestatario de la obligación de abono de las cuotas de amortización de un préstamo"s. Ahora bien, manifestó que ello no impedía que en algunos casos pudiera darse un ejercicio abusivo de estas cláusulas, lo que ocurriría cuando "se prevea la facultad de vencimiento anticipado para incumplimientos irrelevantes, por concurrencia de circunstancias cuya apreciación se deja al puro arbitrio de la entidad bancaria, o cuando se perjudica con su ejercicio de manera desproporcionada y no equitativa al prestatario"6.

2 Vigente hasta el 8 de enero del año 2001.

3 Previsión idénticamente estipulada en el art. 130 de la Ley Hipotecaria de Ultramar de 14 de julio de 1893 y en el art. 127 de la Ley Hipotecaria de 16 de diciembre de 1909.

4 SSTS de 4 de junio de 2008 (RJ 2008\3196); de 12 de diciembre de 2008 (RJ 2009\152); de 16 de diciembre de 2009 (RJ

2010\702) y de 17 de febrero de 2011 (RJ 2011\3316).

5 STS de 4 de junio de 2008 (RJ 2008\3196).

6 STS de 4 de junio de 2008 (RJ 2008\3196).

AGÜERO ORTIZ, Alicia. La abusividad de las cláusulas de vencimiento anticipado en préstamos hipotecario. Revista Justicia y Derecho, Santiago, v. 1, n 1, 2018 
En conclusión, la doctrina jurisprudencial de nuestro Alto Tribunal había reconocido la validez general de las cláusulas de vencimiento anticipado y, especialmente, de las cláusulas de vencimiento anticipado por incumplimiento de una sola cuota por amoldarse a las previsiones normativas en la materia. Con todo, reconoció que se produciría un ejercicio abusivo de la cláusula cuando se previera en caso de incumplimientos irrelevantes, por concurrencia de circunstancias cuya concurrencia se dejara a la apreciación arbitraria del prestamista o cuando se perjudicara desproporcionadamente al prestatario. Por ello, estableció como requisito para su adecuada estipulación, en concreto, la concurrencia de justa causa, entendiendo por tal la existencia de una verdadera y manifiesta dejación de las obligaciones de carácter esencial contraídas como la obligación de pago de las cuotas (incluso de una)

\section{Cambio de paradigma: la postura del Tribunal de Justicia de la Unión Europea sobre la desprotección de los consumidores en el Derecho hipotecario ESPAÑOL}

Como consecuencia de la crisis financiera global, numerosos consumidores se vieron abocados a la insolvencia, viéndose forzados a impagar sus préstamos hipotecarios. En estas circunstancias, los acreedores hipotecarios comenzaron a activar las cláusulas de vencimiento anticipado o aceleración por impago de cualquier parte de capital, como requisito imprescindible para acceder al procedimiento de ejecución hipotecaria. Así pues, comenzaron a declarar el vencimiento anticipado de los préstamos hipotecarios ante el incumplimiento de una cuota del préstamo hipotecario, procediendo subsiguientemente a la ejecución hipotecaria.

Ante la devastadora crisis no solo financiera sino social, jueces y tribunales adoptaron una posición tuitiva de los sujetos ejecutados, tratando de evitar las consecuencias del impago, esto es, la ejecución ${ }^{8}$; o al menos de paliar sus efectos, reduciendo la deuda en lo posible $e^{9}$ Así, comenzó en España lo que podemos llamar la revolución de las cláusulas abusivas. Y decimos revolución, ya que la regulación de las cláusulas abusivas no era novedosa en el Derecho europeo y español. Muy al contrario, el régimen de cláusulas abusivas fue introducido en el Derecho de la Unión Europea mediante la Directiva 93/13/CEE del Consejo, de 5 de abril de 1993, sobre las cláusulas abusivas en los contratos celebrados con consumidores (en adelante, "Directiva 93/13/CEE" o "Directiva"); y estaba ya previsto en la antigua Ley española 26/1984, de 19 de julio, General para la Defensa de los Consumidores y Usuarios, que fue modificada incorporando aquella Directiva, cuyo reflejo consta igualmente en el actual Real Decreto Legislativo 1/2007, de 16 de noviembre, por el que se aprueba el texto refundido de la Ley General para la Defensa de los Consumidores y Usuarios y otras leyes complementarias (en adelante, "TRLGDCU”).

Pues bien, con aquella finalidad tuitiva, jueces y tribunales desempolvaron el régimen de las cláusulas abusivas para mitigar o paralizar los desastrosos efectos de la ejecución hipotecaria. En este sentido, el art. 3.1 de la Directiva 93/13/CEE establece que serán abusivas "[L]as cláusulas contractuales que no se hayan negociado individualmente se considerarán abusivas si, pese a las exigencias de la buena fe, causan en detrimento del consumidor un desequilibrio importante entre los derechos y obligaciones de las partes que se derivan del contrato" (lo que constituye el contenido de nuestro art. 82.1 TRLGDCU). Adicionalmente, la

\footnotetext{
7 SSTS de 16 de diciembre de 2009 (RJ 2010\702) y de 17 de febrero de 2011 (RJ 2011\3316).

8 Precisamente mediante la declaración de abusividad de las cláusulas de vencimiento anticipado.

9 Por ejemplo, declarando la abusividad de comisiones de reclamación de posiciones de deudoras, de las cláusulas suelo, de las cláusulas de gastos de constitución del préstamo hipotecario, etc.
}

AGÜERO ORTIZ, Alicia. La abusividad de las cláusulas de vencimiento anticipado en préstamos hipotecario. Revista Justicia y Derecho, Santiago, v. 1, no 1, 2018 
Directiva contiene un Anexo en el que se establece un listado de cláusulas abusivas que deberá ser considerado en virtud del art. 3.1 anteriormente citado. En particular, el apartado 1. e) refiere a las cláusulas que tengan por objeto o efecto "imponer al consumidor que no cumpla sus obligaciones una indemnización desproporcionadamente alta" (correlativo art. 85.6 TRLGDCU).

Un hito en este sentido constituyó la cuestión prejudicial interpuesta por el Juzgado número 3 de Barcelona ante el Tribunal de Justicia de la Unión Europea (en adelante, "TJUE"), en la que solicitaba, entre otras cuestiones, la delimitación del concepto de desproporción del apartado 1.e) del Anexo de la Directiva 93/13/CEE con la finalidad de determinar si las cláusulas de vencimiento anticipado que permiten vencer el préstamo con el impago de una sola cuota o de cualquier parte de capital e intereses en contratos proyectados a un largo lapso de tiempo -en aquel caso 33 años-constituían cláusulas abusivas en virtud de dicho precepto.

Así las cosas, el TJUE en su famosa sentencia de 14 de marzo de 2013 (caso Aziz) ${ }^{10}$ sostuvo que "corresponde al juez remitente comprobar especialmente, comprobar (...), si la facultad del profesional de dar por vencida anticipadamente la totalidad del préstamo depende de que el consumidor haya incumplido una obligación que revista carácter esencial en el marco de la relación contractual de que se trate, si esa facultad está prevista para los casos en los que el incumplimiento tiene carácter suficientemente grave con respecto a la duración y a la cuantía del préstamo, si dich a facultad constituye una excepción con respecto a las normas aplicables en la materia y si el Derecho nacional prevé medios adecuados y eficaces que permitan al consumidor sujeto a la aplicación de esa cláusula poner remedio a los efectos del vencimiento anticipado del préstamo".

Así pues, establecía el TJUE los requisitos que habrían de analizarse para la evaluación de abusividad de una cláusula de vencimiento anticipado: (i) que el incumplimiento que active la cláusula sea esencial; (ii) que el incumplimiento que active la cláusula sea suficientemente grave respecto a la duración y cuantía del préstamo; (iii) que la facultad de vencer anticipadamente no constituya una excepción con respecto a las normas aplicables en la materia "de manera que resulte más difícil para el consumidor, a la vista de los medios procesales de que dispone, el acceso a la justicia y el ejercicio de su derecho de defensa"11; y que (iv) el Derecho nacional prevea medios adecuados para que el consumidor pueda liberarse de los efectos del vencimiento anticipado.

En consecuencia, correspondía al juez nacional que conociera del proceso de ejecución hipotecaria evaluar si la cláusula de vencimiento anticipado o aceleración por incumplimiento de una sola cuota era abusiva por permitir dicha aceleración ante incumplimientos no esenciales ni suficientemente graves en relación con la duración y cuantía del préstamo, abusividad que fue reconocida generalmente, con los matices que analizaremos más adelante.

Esta sentencia del TJUE propició la promulgación de la Ley 1/2013, de 14 de mayo, de medidas para reforzar la protección a los deudores hipotecarios, reestructuración de deuda y alquiler social (en adelante, "Ley 1/2013"), que modificaba la LEC en varios sentidos, por lo que aquí interesa se modificó el artículo 693 exigiendo ahora el incumplimiento de tres mensualidades para poder proceder a la declaración del vencimiento anticipado en los préstamos garantizados. En concreto, establece el actual art. 693.1 y 2 de la LEC que"1. Lo dispuesto en este Capítulo será aplicable al caso en que deje de pagarse una parte del capital del crédito o los intereses, cuyo pago deba hacerse en plazos, si vencieren al menos tres plazos mensuales sin cumplir el deudor su obligación de pago o un número de cuotas tal que suponga que el deudor ha incumplido su obligación por un plazo al menos equivalente a tres meses. Así se hará constar por el Notario en la escritura

10 TJCE 2013\89.

11 Definición del requisito añadida en el Auto del TJUE de 14 de noviembre de 2013, en los asuntos acumulados C-537/12 Banco Popular Español/Rivas Quichimbo y Cun Pérez y C-116/13 Banco de Valencia/Valldeperas Tortosa y Miret Jaume.

AGÜERO ORTIZ, Alicia. La abusividad de las cláusulas de vencimiento anticipado en préstamos hipotecario. Revista Justicia y Derecho, Santiago, v. 1, n 1, 2018 
de constitución. (...) 2. Podrá reclamarse la totalidad de lo adeudado por capital y por intereses si se hubiese convenido el vencimiento total en caso de falta de pago de, al menos, tres plazos mensuales sin cumplir el deudor su obligación de pago o un número de cuotas tal que suponga que el deudor ha incumplido su obligación por un plazo, al menos, equivalente a tres meses, y este convenio constase en la escritura de constitución".

Tras estos dos hitos en materia de cláusulas de vencimiento anticipado muchas han sido las dudas que han surgido al respecto. En particular, parecía quedar claro que el vencimiento anticipado por impago de una cuota no debía ser considerado esencial ni suficientemente grave, pero tras la modificación del art. 693 LEC en el sentido de exigir el incumplimiento equivalente a tres cuotas, ¿debía considerarse no abusiva la cláusula que previera el vencimiento anticipado por un incumplimiento equivalente a tres mensualidades? En otras palabras, ¿supone el art. 693 LEC un criterio de abusividad, esto es, por el mero hecho de que una cláusula reproduzca el art. 693 de la LEC debe ser considerada no abusiva? Es más, dado que la absoluta mayoría de hipotecas que están siendo ejecutadas fueron suscritas antes de la modificación del precepto en 2013 y, por ende, preveían la aceleración del préstamo ante el incumpliendo de cualquier parte de capital o intereses, ¿podría estimarse que la cláusula no era abusiva si, a pesar de la redacción de la cláusula, el acreedor esperó de facto al incumplimiento de más de tres cuotas para vencer anticipadamente el préstamo? A mayor abundamiento, dado que el art. 1.2 de la Directiva 93/13/ CEE recoge el llamado principio de presunción de adecuación de la normativa nacional al Derecho europeo $^{12}$, ¿puede considerarse que las cláusulas de vencimiento anticipado están excluidas del control de abusividad si reproducen el art. 693 LEC en la redacción vigente en el momento de la contratación?

\section{Las CLÁUsUlas de VENCIMIENTO ANTICIPADO QUE REPRODUZCAN EL ART. 693 LEC NO ESTÁN EXENTAS DEL CONTROL DE ABUSIVIDAD POR APLICACIÓN DEL PRINCIPIO DE PRESUNCIÓN DE ADECUACIÓN}

La Directiva 93/13/CEE establece en su artículo 1.2 que "[L]as cláusulas contractuales que reflejen disposiciones legales o reglamentarias imperativas, así como las disposiciones o los principios de los convenios internacionales, en especial en el ámbito de los transportes, donde los Estados miembros o la Comunidad son parte, no estarán sometidos a las disposiciones de la presente Directiva". Es el conocido como "principio de presunción de adecuación" que se enuncia con mayor extensión en el Considerando decimotercero de la Directiva 93/13/CEE según el cual "[C]onsiderando que se supone que las disposiciones legales o reglamentarias de los Estados miembros por las que se fijan, directa o indirectamente, las cláusulas de los contratos celebrados con los consumidores no contienen cláusulas abusivas; que por consiguiente, no resulta necesario someter a las disposiciones de la presente Directiva las cláusulas que reflejan las disposiciones legales o reglamentarías imperativas ni las disposiciones de convenios internacionales de los que los Estados miembros o la Comunidad sean parte; que a este respecto, la expresión «disposiciones legales o reglamentarias imperativas» que aparece en el apartado 2 del artículo 1 incluye también las normas que, con arreglo a derecho, se aplican entre las partes contratantes cuando no exista ningún otro acuerdo".

Asimismo, diversas SSTJUE'13 han reiterado que "la Directiva 93/13/CEE del Consejo, de 5 de abril de 1993,

12 En concreto, el precepto reza: "Las cláusulas contractuales que reflejen disposiciones legales o reglamentarias imperativas, así como las disposiciones o los principios de los convenios internacionales, en especial en el ámbito de los transportes, donde los Estados miembros o la Comunidad son parte, no estarán sometidos a las disposiciones de la presente Directiva".

13 Asuntos Vertrieb C-92/11, Jahani C-488/11, Banco Popular Español C-537/12 y 116/13, Smart Capital C-34/13), sentencia de 30 abril de 2014, Caso Barclays Bank, S.A., (C-280/13).

AGÜERO ORTIZ, Alicia. La abusividad de las cláusulas de vencimiento anticipado en préstamos hipotecario. Revista Justicia y Derecho, Santiago, v. 1, n 1, 2018 
sobre las cláusulas abusivas en los contratos celebrados con consumidores, y los principios del derecho de la Unión relativos a la protección de los consumidores y al equilibrio contractual deben interpretarse en el sentido de que están excluidas de su ámbito de aplicación las disposiciones legales y reglamentarias de un Estado miembro, como las controvertidas en el litigio principal, cuando no existe una cláusula contractual que modifique el alcance o el ámbito de aplicación de tales disposiciones". La ratio del principio de presunción de adecuación es que las cláusulas que reflejan una norma han contado con la aprobación del legislador nacional, sin imponer ni responder a un abuso o superioridad de la posición empresarial en perjuicio del consumidor, por lo que no causan un desequilibrio entre las partes, y cuentan con la buena fe del predisponente que se limita a transcribir el contenido de una norma.

En este contexto, algunos autores han considerado que las cláusulas de vencimiento anticipado que reprodujeran la dicción literal del art. 693 LEC antes de su reforma por la Ley 1/2013, debían ser ajenas al control de abusividad en aplicación del principio de presunción de adecuación ${ }^{14}$. Esta cuestión ha sido también cuestionada por nuestros órganos judiciales, en concreto, la Audiencia Provincial de Pontevedra en su sentencia de 31 de octubre de 2015, declara que no es aplicable el art. 1.2 de la Directiva en una cláusula como la expuesta ut supra ya que "[E]n el presente caso, la cláusula empleada por la entidad bancaria ejecutante no se limita a recoger la posibilidad de que las partes "convengan la facultad a favor del acreedor", sino que materializa el pacto y define su aplicación, concretando el presupuesto exigido para su aplicación en términos que la ley no especifica ni legitima". Por el contrario, algunos magistrados del Pleno Jurisdiccional de las Secciones Civiles de la Audiencia Provincial de Sevilla15, plantearon un voto particular en el que sostuvieron que las cláusulas de vencimiento anticipado son válidas si se ajustan al contenido del art. 693 LEC en el momento del otorgamiento de la escritura pues no pueden ser sometidas al control de abusividad en virtud del reiterado principio de presunción de adecuación.

Sin embargo, el verdadero problema radica en determinar si el art. 693 LEC constituye una norma imperativa o derecho supletorio, de forma tal que pueda entenderse incluida en el art. 1.2 Directiva. En concreto, porque el apartado segundo de dicho precepto exigía que el pacto de vencimiento anticipado se hubiera convenido entre las partes y constase inscrito en el Registro de la Propiedad ${ }^{16}$.

Esta cuestión fue abordada recientemente por el TJUE en su sentencia de 26 de enero de $2017^{17}$, en la que daba respuesta las cuestiones prejudiciales planteadas por el Juzgado de Primera Instancia no 2 de Santander. En este sentido, el Abogado General Maciej Szpunar negó en sus conclusiones ${ }^{18}$ que cupiera concebir que estas cláusulas pudieran entenderse comprendidas en el art. 1.2 de la Directiva (principio de presunción de adecuación) ya que el art. 693 LEC no constituye una disposición normativa aplicable en ausencia de pacto, esto es, no constituye una norma imperativa ni de derecho supletorio. Contrario a esta postura se manifiesta MARTín (2017), 106 ${ }^{19}$ quien sostiene que "concepto disposición legal o reglamentaria imperativa se está refiriendo a todo el Derecho vigente aplicable a un determinado tipo de contrato, sin que el legislador comunitario quisiera diferenciar entre categorías de normas".

EITJUE alcanzó las mismas conclusiones, pero por razones diversas. Lejos de sostener que las cláusulas que reprodujeran el artículo 693.2 LEC caían dentro del ámbito de aplicación de la Directiva 93/13/CEE

14 GIMÉNEZ (2016). VLEX-632337681.

15 Acuerdo del Pleno Jurisdiccional de las Secciones Civiles de la Audiencia Provincial de Sevilla, Auto de 23 de marzo de 2017 (AC 2017\438).

16 693.2 LEC: "Podrá reclamarse la totalidad de lo adeudado por capital y por intereses si se hubiese convenido el vencimiento total en caso de falta de pago de alguno de los plazos diferentes y este convenio constase inscrito en el Registro".

1722.

18 Conclusiones del abogado general Sr. Maciej Szpunar presentadas el 2 de febrero de 2016 (Asunto C-421/14).

19 MarTín (2017).

AGÜERO ORTIZ, Alicia. La abusividad de las cláusulas de vencimiento anticipado en préstamos hipotecario. Revista Justicia y Derecho, Santiago, v. 1, n 1, 2018 
por no constituir una norma imperativa o supletoria -como habría sido razonable y como ya había apuntado el Abogado General-, el TJUE sostuvo que la cláusula litigiosa no reproducía aquella disposición, por lo que dicha cláusula sí que está amparada por la Directiva 93/13/CEE. Sin embargo, consideró que la cláusula litigiosa -suscrita antes de la modificación operada por la Ley 1/2013- no reproducía el art. 693 LEC puesto que la contrastó con la redacción actual del precepto (que exige el incumplimiento de un importe equivalente a tres mensualidades) y no con la redacción vigente en el momento de la contratación. La resolución del TJUE es desacertada, porque no responde a la cuestión esencial para la controversia surgida en la jurisprudencia de los tribunales españoles, a saber, si en caso de que una cláusula reprodujera el artículo 693.2 LEC (vigente en el momento de la contratación), debería entenderse que dicha cláusula está excluida del ámbito de aplicación de la Directiva 93/13/CEE.

En conclusión, tras la STJUE de 26 de enero $2017^{20}$ se mantiene la incertidumbre sobre si las cláusulas de vencimiento anticipado que reproduzcan el artículo 693.2 LEC, en la redacción vigente en el momento de suscribir el préstamo hipotecario, están o no están excluidas del ámbito de aplicación de la Directiva 93/13/CEE en virtud de su artículo 1.2, puesto que la sentencia no arroja luz esta cuestión, sino todo lo contrario.

\section{El ART. 693 LEC CONSTITUYE UN LÍMITE DE LEGALIDAD PERO NO DE ABUSIVIDAD}

Habida cuenta de la incertidumbre respecto a si las cláusulas que reproduzcan el art. 693 LEC deben comprenderse excluidas del control de abusividad en virtud del principio de presunción de adecuación, procede ahora evaluar si el nuevo requisito de tres incumplimientos constituye un criterio de abusividad. Dicho de otro modo, si debe reputarse que las cláusulas que prevean el vencimiento anticipado en caso de incumplimiento equivalente a tres mensualidades son válidas y no abusivas.

EI TJUE ha reiterado en este sentido que "Ios artículos 3, apartado 1, y 4, apartado 1, de la Directiva 93/13 no permiten que la apreciación, por parte del juez nacional, del carácter abusivo, en el sentido de esta Directiva, de una cláusula de un contrato de préstamo hipotecario que fija el tipo de los intereses de demora y de una cláusula del mismo contrato que determina las condiciones del vencimiento anticipado del préstamo quede limitada a criterios como los definidos en el artículo 114 de la Ley Hipotecaria y en el artículo 693 de la LEC". Concluyendo que los arts. 3.1 y 4.1 de la Directiva 93/13/CEE "no permiten que el Derecho de un Estado miembro restrinja la facultad de apreciación del juez nacional en lo que se refiere a la constatación del carácter abusivo de las cláusulas de un contrato de préstamo hipotecario celebrado entre un consumidor y un profesional [y es que] los criterios establecidos en relación con la aplicación de dichas disposiciones nacionales no pueden, pues, prejuzgar por sí solos e inevitablemente la apreciación, por parte del juez nacional, del carácter "abusivo» en el sentido del artículo 3 de la Directiva 93/13 de una cláusula que fija los intereses de demora y de una cláusula que precisa los requisitos del rembolso anticipado de un préstamo hipotecario"21.

En síntesis, el carácter abusivo de una cláusula no puede quedar prejuzgado ni predeterminado por una norma, pues es el juez, caso por caso, quien debe determinar si la cláusula es abusiva, a la luz de los criterios trazados por el TJUE. Por las mismas razones, "el mero hecho de que la cláusula de vencimiento

20 JUR 2017 26895.

21 Auto TJUE de 17 marzo 2016 (JUR 2016\105998). Como ya hubiera hecho respecto al art. 114.3 LH que limita los intereses moratorios en préstamos hipotecarios que recaigan sobre la vivienda habitual a tres veces el interés legal del dinero, en sus Autos de 11 de junio de 2015 (TJCE\2015\224) y de 8 de julio de 2015 (TJCE 2015\280), y reiteró la STJUE de 26 de enero de 2017 (TJCE 2017\31).

AGÜERO ORTIZ, Alicia. La abusividad de las cláusulas de vencimiento anticipado en préstamos hipotecario. Revista Justicia y Derecho, Santiago, v. 1, n 1, 2018 
anticipado sobre la que versa el litigio principal resulte contraria al artículo 693, apartado 2, de la Ley de Enjuiciamiento Civil no permite por sí solo llegar a la conclusión del carácter abusivo de dicha cláusula"22.

En consecuencia, la vulneración de las cláusulas de vencimiento anticipado estipuladas tras la entrada en vigor de la Ley 1/2013 del requisito del art. 693 de la LEC, es decir, las cláusulas que tras la entrada en vigor de la Ley 1/2013 establezcan que se pueda declarar vencido anticipadamente el préstamo hipotecario serán ilegales y, por ende, no permitirán el acceso al procedimiento ejecutivo especial para bienes hipotecarios y pignorados -la demanda habría de ser inadmitida-. Ahora bien, ello no supone que dichas cláusulas puedan ser reputadas abusivas automáticamente aunque por ser contrarias a la norma serán nulas. Esto significa, igualmente, que una cláusula que cumpla con los requisitos de la norma -que prevea el vencimiento anticipado en caso de incumplimiento de tres mensualidades- puede ser considerada abusiva, aun cuando sea legal ${ }^{23}$. Con todo, el requisito de tres incumplimientos del art. 693.2 LEC puede ser utilizado por los jueces como parámetro para evaluar la abusividad de la cláusula litigiosa, pues como expusimos, dos de los elementos que ha de evaluar el juez es la excepcionalidad de la medida respecto al ordenamiento nacional y las medidas impuestas por el ordenamiento interno en caso inexistencia de dicha cláusula.

\section{Cláusulas redactadas antes de la reforma del art. 693 LEC: ¿Apreciación DE LA ABUSIVIDAD DE LA DICCIÓN LITERAL DE LA CLÁUSULA O DEL EFECTIVO EJERCICIO DE LA MISMA POR EL ACREEDOR?}

El tercer problema que plantean las cláusulas de vencimiento anticipado refiere al destino que han de correr las cláusulas que fueron redactadas antes de la reforma de la Ley 1/2013 y la incidencia de la forma en que el acreedor las aplique. En otras palabras, ¿estas cláusulas han de ser reputadas abusivas si su dicción literal permite el vencimiento anticipado por impago de una cuota incluso cuando el acreedor esperó a que se produjeran más de tres incumplimientos para vencer anticipadamente?

La mayor parte de jueces y tribunales adoptaron como criterio interpretativo de abusividad el requisito de tres incumplimientos del nuevo art. 693 LEC. Ahora bien, como es evidente, este requisito resultaría de aplicación exclusivamente a la actuación del acreedor pues lo cierto es que ninguna cláusula estaba redactada de conformidad con un artículo que no se publicaría sino años después. Consecuentemente, la mayor parte de las Audiencias Provinciales ${ }^{24}$ se inclinaron por evaluar la abusividad del vencimiento anticipado de conformidad con el número de plazos que el acreedor hubiera dejado correr antes de ejercitarlo, con independencia de que la letra de la cláusula le permitiera hacerlo por cualquier incumplimiento (incluso uno).

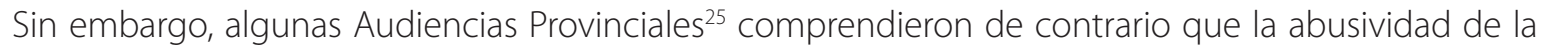

\footnotetext{
22 ATJUE de 11 de junio de 2015 (TJCE 2015\224).

23 Como sostiene Fernández Seljo, J.M.: "Algunas dudas wittgensteinianas sobre los efectos de la declaración de abusividad de una condición general", en "¿Cuáles son los efectos de la nulidad de la cláusula de vencimiento anticipado inserta en contratos de préstamo hipotecario suscrito con consumidores? En concreto, ¿la nulidad de la cláusula impide acudir al procedimiento de ejecución hipotecaria?". FERnÁndez (2016).

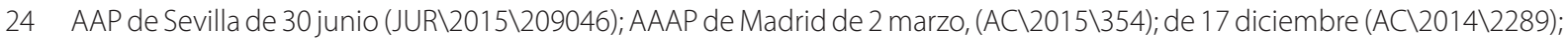

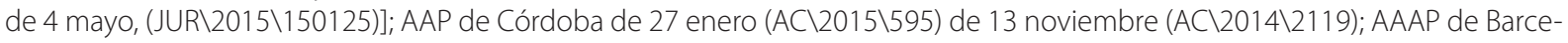

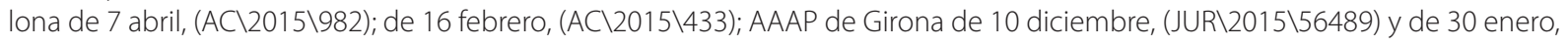

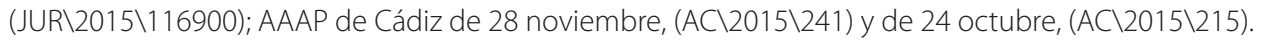

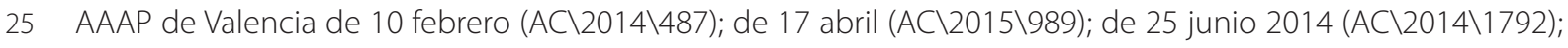

AGÜERO ORTIZ, Alicia. La abusividad de las cláusulas de vencimiento anticipado en préstamos hipotecario. Revista Justicia y Derecho, Santiago, v. 1, nº 1, 2018 
cláusula de vencimiento anticipado debía analizarse de conformidad con la literalidad de su redacción, lo que MARTíN (2016), $1^{26}$ ha denominado "en abstracto", con independencia de que el acreedor hubiera esperado varios incumplimientos para vencer anticipadamente el préstamo. En este contexto, el Juez del Juzgado de Primera Instancia no 2 Santander remitió una cuestión prejudicial al TJUE, resuelta mediante su Auto de 11 de junio de 201527. En concreto se planteaba "[S]i de conformidad con la Directiva 93/13/CEE del Consejo, de 5 de abril de 1993, sobre las cláusulas abusivas en los contratos celebrados con consumidores, y en particular de sus artículos 6.1 y 7.1, a fin de garantizar la protección de consumidores y usuarios de acuerdo con los principios de equivalencia y efectividad cuando un juez nacional aprecie la existencia de una cláusula abusiva acerca del vencimiento anticipado debe deducir tenerla por no puesta y extraer las consecuencias a ello inherentes incluso aun cuando el profesional haya esperado el tiempo mínimo previsto en la norma nacional".

EITJUE resolvió sosteniendo que la evaluación de abusividad de una cláusula no puede estar supeditada a que la cláusula se haya aplicado o no realmente, sin embargo, el hecho de que deban evaluarse todas las circunstancias concurrentes para determinar la abusividad de una cláusula, no excluye que se pueda tomar en consideración este ejercicio corrector del acreedor. En cualquier caso, el juez nacional no puede decretar la no abusividad de la cláusula por el único hecho de que el prestamista no la haya aplicado, pues deben tomarse en consideración todos los criterios expuestos ut supra. En sus propias palabras: "las prerrogativas del juez nacional que constata la existencia de una "cláusula abusiva» (...) no pueden estar supeditadas a que la cláusula abusiva se aplique o no en la práctica. (...) Por consiguiente, (...) cuando el juez nacional haya constatado el carácter «abusivo» (...) de una cláusula de un contrato celebrado entre un consumidor y un profesional, la circunstancia de que tal cláusula no haya llegado a aplicarse no se opone por sí sola a que el juez nacional deduzca todas las consecuencias oportunas del carácter abusivo de la cláusula en cuestión". Con mayor rigidez se pronunció el Abogado General Maciej Szpunar en sus conclusiones de 2 de febrero de $2016^{28}$ al mantener que "el hecho de que la entidad bancaria no diera inicio al procedimiento de ejecución hipotecaria hasta el impago de siete mensualidades consecutivas es un elemento fáctico que no ha de tenerse en cuenta en la apreciación de un a cláusula contractual que tenía en realidad por objeto permitir a la entidad bancaria proceder a la ejecución hipotecaria en caso de impago de una sola mensualidad. Cabe observar, a este respecto, que, en el ámbito de la protección de los consumidores, un comportamiento razonable en un marco contractual abusivo no priva a una cláusula de su carácter abusivo".

De este modo, el Tribunal Supremo en sus sentencias de 23 de diciembre de $2015^{29}$ y de 18 de febrero de $2016^{30}$, siguió el criterio del TJUE considerando que la abusividad de la cláusula de vencimiento anticipado debía efectuarse en abstracto, pero no con absoluta independencia respecto a cómo la hubiera ejecutado el prestamista, incluso cuando la primera de aquellas no traía como causa una ejecución hipotecaria sino una acción colectiva.

Por lo que ahora importa, en ambos pronunciamientos declaró que "parece evidente que una cláusula de vencimiento anticipado que permite la resolución con el incumplimiento de un solo plazo, incluso parcialy respecto de una obligación accesoria, debe ser reputada como abusiva, dado que no se vincula a parámetros cuantitativa o temporalmente graves. (...) conforme a la interpretación que de dicho precepto ha hecho el TJUE en el Auto de 11 de junio de 2015, al decir «(...) la circunstancia de que tal cláusula no haya llegado a

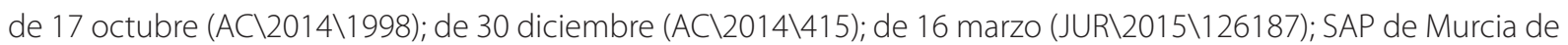

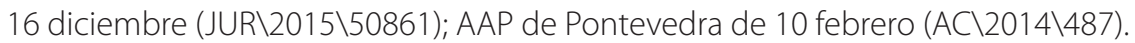

26 MARTíN (2016).

27 TJCE\2015\224.

28 Conclusiones del abogado general Sr. Maciej Szpunar presentadas el 2 de febrero de 2016 (Asunto C-421/14).

29 RJ $2015 \backslash 5714$ (apartado f.2); RJ 20161619 (segundo motivo, 2).

30 RJ $2016 \backslash 619$.

AGÜERO ORTIZ, Alicia. La abusividad de las cláusulas de vencimiento anticipado en préstamos hipotecario. Revista Justicia y Derecho, Santiago, v. 1, n 1, 2018 
aplicarse no se opone por sísola a que el juez nacional deduzca todas las consecuencias oportunas del carácter abusivo de la cláusula en cuestión». Es decir, ante el pacto de vencimiento anticipado en un contrato celebrado con consumidores y siempre que se cumplan las condiciones mínimas establecidas en el art. 693.2 LEC, los tribunales deben valorar, además, en el caso concreto, si el ejercicio de la facultad de vencimiento anticipado por parte del acreedor está justificado, en función de los criterios antes expuestos: esencialidad de la obligación incumplida, gravedad del incumplimiento en relación con la cuantía y duración del contrato de préstamo y posibilidad real del consumidor de evitar esta consecuencia; tal como estableció la ya mencionada STJUE de 14 de marzo de 2013 (TJCE 2013, 89) (caso C-415/11)".

Finalmente, la STJUE de 26 de enero de $2017^{31}$ reiteró que la circunstancia de que, en este caso, el profesional haya observado en la práctica lo dispuesto en el artículo 693, apartado 2, de la LEC y no haya iniciado el procedimiento de ejecución hipotecaria hasta que se produjo el impago de siete mensualidades, en lugar de en el momento en que se produjo la falta de pago de cualquier cantidad adeudada, no exime al juez nacional de su obligación de deducir todas las consecuencias oportunas del eventual carácter abusivo de esa cláusula.

En otras palabras, queda ya aclarado que la declaración de abusividad de la cláusula debe realizarse en función de su propia redacción y a la luz de las directrices sentadas por el TJUE desde la sentencia de 14.3.2013 (caso Aziz) del empresario no exime al juez nacional de su obligación de deducir todas las consecuencias oportunas del eventual carácter abusivo de esa cláusula.

\section{LA falta de pago en SUS Vencimientos de "CUALQUier PARTE del CAPITAL DEL PRÉSTAMO O SUS INTERESES" TAMBIÉN INCLUYE TRES O MÁS INCUMPLIMIENTOS}

Incluso aceptando que la cláusula debe evaluarse conforme a su literalidad, las dudas respecto a su validez no quedan disipadas. Así, se erige el argumento según el cual por más que se haya venido llamando a estas cláusulas como cláusulas de vencimiento anticipado por un solo incumplimiento, lo cierto es que no es ese el contenido de sus redacciones. Estas cláusulas no establecen que se pueda vencer "por un incumplimiento" de forma exclusiva y excluyente, como si por dos incumplimientos no estuviera facultado el acreedor a vencer anticipadamente. Por el contrario, lo que manifiestan estas cláusulas es que se podrá vencer por el incumplimiento de pago de "cualquier parte" del importe debido. En este sentido, se interpreta que cuando el acreedor declara vencido anticipadamente un préstamo transcurridos ocho incumplimientos, no está ejercitando una acción ajena al contenido de la cláusula. Está aplicando la cláusula en sus propios términos fijando su contenido evaluable mediante su ejercicio ${ }^{32}$.

En otras palabras, si dispuesta una cláusula que permite al acreedor vencer anticipadamente por cualquier incumplimiento, y aceptado generalmente que las cláusulas de vencimiento anticipado tras ocho incumplimientos no son abusivas -por ejemplo-, cuando el acreedor ejecute su cláusula tras el transcurso de ocho mensualidades la parte de la cláusula aplicada no es abusiva. Por el contrario, sí sería abusiva la parte de la cláusula que permitiera al acreedor vencer anticipadamente tras un solo incumplimiento. Es decir, dado que la cláusula permite vencer anticipadamente cuando se produzcan de 1 a 1+n incumplimientos (número total de vencimientos), la parte de la cláusula que resultaría abusiva es exclusivamente aquella que permita el vencimiento sin cumplirse los criterios señalados por el TJUE. En nuestro ejemplo,

31 JUR 2017\26895.

32 CaRrasco (2015).

AGÜERO ORTIZ, Alicia. La abusividad de las cláusulas de vencimiento anticipado en préstamos hipotecario. Revista Justicia y Derecho, Santiago, v. 1, n 1, 2018 
el contenido de la cláusula que debería considerarse nulo y expulsarse del contrato es el que permite el ejercicio de la cláusula de 1 a 7 incumplimientos, siendo válida la cláusula en resto de su contenido (pues alberga todas esas posibilidades), es decir, desde 8 incumplimientos hasta $8+n$.

La Audiencia Provincial de Madrid, en su Auto de 29 de junio de 201633, ha compartido este criterio declarando "[P]or lo tanto habría sido abusiva la aplicación de esa cláusula si sólo hubiera existido ese incumplimiento que no era suficientemente grave, pero no ha sido tal el caso puesto que fueron en realidad nueve las cuotas impagadas cuando se declaró tal vencimiento. Y como no ha sido el caso y no nos hallamos ante un proceso declarativo en el que se inste la nulidad de una cláusula, no es acogible esa causa de oposición puesto que no concurre el supuesto del arto. $6954^{\circ}$ LEC ya que el impago de una sola cuota no es el fundamento de la ejecución ni esa cláusula se aplica para determinar la cantidad exigible". En opinión de la AP, dado que la cláusula comprende de uno a $1+n$ incumplimientos, cuando se venza anticipadamente el préstamo por nueve incumplimientos -siempre que dicho incumplimiento se considere esencial, suficientemente grave, etc.- la cláusula que fundamenta la ejecución es la que permite el vencimiento anticipado por nueve incumplimientos -que es lo acontecido y lo que la cláusula prevé-. Consecuentemente, dado que art. 695.4 LEC sólo permite oponer en el procedimiento ejecutivo hipotecario la existencia de cláusulas abusivas que constituyan el fundamento de la ejecución, no puede oponerse la abusividad de la cláusula de incumplimiento por una cuota puesto que el incumplimiento de una sola cuota no fue un incumplimiento el que fundamentó la ejecución.

A este respecto, el TS ha interpuesto una cuestión prejudicial mediante auto de 8 de febrero de $2017^{34}$, en la que consulta al TJUE si se permite, al enjuiciar la abusividad de una cláusula, separar, en determinados casos, el elemento abusivo del elemento válido, de manera que este último pueda mantener su vinculación y eficacia tras la declaración de nulidad del elemento abusivo ("blue pencil rule"). ${ }^{35}$ Además, la Sala Primera considera que la aplicación de esta doctrina no sería contraria a la Directiva 93/13, porque el juez no integra o sustituye la cláusula declarada nula por abusiva, sino que simplemente delimita y expulsa de la cláusula el elemento abusivo. La cuestión no ha sido aún resuelta y no podemos aportar ninguna previsión, ya que no nos consta que el TJUE se haya pronunciado a este respecto con anterioridad.

\section{Los EFECTOS DE LA DECLARACIÓN DE ABUSIVIDAD DE LA CLÁUSULA DE VENCIMIENTO ANTICIPADO. ESPECIAL REFERENCIA A LAS SSTS DE 23 DE DICIEMBRE DE 2015 Y DE 18 DE FEBRERO DE 2016}

Desde la antigua STJUE de 14 de junio de $2012^{36}$ quedó aclarado que el efecto de la declaración de abusividad de las cláusulas es su expulsión del contrato sin caber moderación ni integración de las mismas. En el caso de cláusula de vencimiento anticipado, su expulsión del contrato comportaría la imposibilidad de acceder al proceso ejecutivo de bienes hipotecados o, caso de haberse iniciado, el sobreseimiento de la ejecución ${ }^{37}$. En palabras de FERNÁNDEZ (2016), 48 "[S]i la cláusula se declara nula

\footnotetext{
33 JUR 2016\184356.

34 RJ 2017\365.

35 Martínez (2017).

36 TJCE 2012\143.

37 SANJUÁN Y MUÑOZ, E. sostiene con rotundidad que "La cuestión se aborda en cualquier caso desde la aplicación de lo previsto en el artículo 695.1.4 y 3.2० de la LEC 1/2000: si se declara el carácter abusivo de una cláusula contractual que constituya el fundamento de la ejecución o que hubiese determinado la cantidad exigible, se acordará el sobreseimiento de la ejecución cuando la cláusula contractual fundamente la ejecución". SANJuÁN y MuÑoz (2016).

38 "Algunas dudas wittgensteinianas sobre los efectos de la declaración de abusividad de una condición general". En “¿Cuáles
}

AGÜERO ORTIZ, Alicia. La abusividad de las cláusulas de vencimiento anticipado en préstamos hipotecario. Revista Justicia y Derecho, Santiago, v. 1, n 1, 2018 
entiendo que la consecuencia no debería ser la integración del contrato. Desde el momento en el que se declara la nulidad el efecto no puede ser otro que el de dejar sin efecto el despacho de ejecución, si la cláusula de vencimiento anticipado es nula querrá decir que la cantidad reclamada ni es líquida, ni es vencida, ni es exigible; el ejecutante solicita el despacho de ejecución por la totalidad de las cuotas con los intereses y correctivos correspondientes, sin embargo la cantidad realmente líquida y exigible es la de las cuotas no satisfechas"39.

En el seno de la litigiosidad relativa a las cláusulas de vencimiento anticipado, los AATJUE de 11 de junio de 2015, de 17 de marzo de 2016, y las conclusiones del Abogado General 2 de febrero de 2016 (asunto C-421/14) habían reiterado la imposibilidad de moderar o integrar la cláusula declarada abusiva, con la excepción de la posibilidad que se reconoce al juez de sustituir la cláusula por una disposición supletoria de Derecho nacional siempre que la nulidad de la cláusula comportase la nulidad del contrato por completo, situando al consumidor en peor situación. Pese a las disquisiciones doctrinales, los jueces y tribunales españoles no dudaban en ordenar el sobreseimiento de la ejecución una vez declarada la cláusula de vencimiento anticipado.

Todo cambió con las sentencias de 23 de diciembre de $2015^{40}$ y de 18 de febrero de $2016^{41}$ del Tribunal Supremo. En ellas el TS decretó la abusividad de las cláusulas de vencimiento anticipado por considerar que no respetaban los requisitos de abusividad establecidos por el TJUE, pero declaró que dicha nulidad no debía comportar la eliminación de la cláusula -pudiendo el acreedor acceder a la ejecución hipotecaria o no verla sobreseída en caso de hallarse en este estadio-. Esta decisión se fundamentó sobre tres criterios: la protección al mercado hipotecario; la protección a los consumidores; y la protección a los prestamistas $^{42}$.

Respecto al primer criterio, sostuvo que: "[L]a tutela de los consumidores aconseja evitar interpretaciones maximalistas, que bajo una apariencia de máxima protección, tengan como consecuencia paradójica la restricción del acceso al crédito hipotecario y, derivadamente, a la adquisición de vivienda en propiedad". Ciertamente, la litigiosidad surgida en materia de cláusulas abusivas abusivas en préstamos de toda índole está encareciendo el crédito y restringiendo el acceso al mismo, pero ello no significa que puedan dejar de aplicarse las consecuencias de la abusividad declarada.

En relación con el segundo criterio, continuó recordando los requisitos establecidos por el TJUE para proceder a la sustitución de una cláusula abusiva por una disposición "supletoria" de Derecho nacional, esto es, que la declaración de nulidad obligue al juez a anular el contrato en su totalidad de forma que

son los efectos de la nulidad de la cláusula de vencimiento anticipado inserta en contratos de préstamo hipotecario suscrito con consumidores? En concreto, ¿la nulidad de la cláusula impide acudir al procedimiento de ejecución hipotecaria?" Revista Consumo y Empresa - Núm. 1, febrero 2016.

39 En contra: ANTÓN GUIJARRO, J. quien interpreta que "si la cláusula fuera manifiestamente nula por contemplar la posibilidad de vencimiento anticipado por debajo del umbral permitido por el nuevo art. 693-2 LEC (por ej., con el impago de una sola cuota), no por ello debe quedar cercenada la vía ejecutiva, pues la desaparición de esa cláusula genera una laguna que debe ser colmada. Como señala el profesor José María Miquel, el control de abusividad no es más que la comparación de la cláusula con un parámetro que viene dado por la norma que resultaría de aplicación en el caso de que las partes no hubieran pactado dicha cláusula. (...) En consecuencia, si ha existido un incumplimiento por parte del deudor de una entidad suficiente para poder ser tenido como un incumplimiento resolutorio, la entidad financiera podrá declarar resuelto el contrato conforme a la regla general del art. 1124 C.Civil y con ello tener por vencida anticipadamente la operación de conformidad con el art. 1129 C. Civil". Así como, HERNÁNDEZ RODRíGUEZ, M.M. que considera "que cabría acudir a la ejecución hipotecaria a pesar de la nulidad de la cláusula de vencimiento anticipado cuando sea el propio deudor el que entienda que le es más beneficioso dicho procedimiento (lo que resultará por definición incompatible con la invocación de dicha nulidad) o cuando el vencimiento anticipado se haya producido por otras causas admitidas en nuestro derecho como es por la pérdida del beneficio del plazo". FERnÁndez et al. (2016).

40 RJ $2015 \backslash 5714$ (apartado f.2); RJ $2016 \backslash 619$ (segundo motivo, 2).

41 RJ 2016\619.

42 AdAN (2016).

AGÜERO ORTIZ, Alicia. La abusividad de las cláusulas de vencimiento anticipado en préstamos hipotecario. Revista Justicia y Derecho, Santiago, v. 1, nº 1, 2018 
el consumidor quede expuesto en una condición más perjudicial ${ }^{43}$. Considerando que esto es lo que sucedería si se "cerrara el acceso al proceso de ejecución hipotecaria (... ); ya que no puede considerarse que el sobreseimiento de la vía ejecutiva hipotecaria sea en todo caso más favorable al consumidor". Así, enumeró los pretendidos beneficios que el procedimiento de ejecución hipotecaria ofrece al consumidor, a diferencia del proceso declarativo: (i) posibilidad de liberar el bien en virtud del art. 693.3 LEC; (ii) posibilidad de liberarse de la deuda pendiente de pago tras la ejecución insuficiente del bien si abonara un 65\% de la deuda dentro del plazo de cinco años, o el 80\% de la deuda dentro de los diez años (art. 579 LEC); (iii) la posibilidad de obtener un 50\% de la plusvalía obtenida por el ejecutante si vendiera el bien dentro de los diez años posteriores a la aprobación de rebaja en la deuda pendiente de pago (art. 579 LEC); (iv) la fijación de un importe mínimo por el que el bien podrá ser adjudicado en subasta, a saber, 70\% del valor de tasación que sirvió para conceder el préstamo; y (v) inexistencia de mayores motivos de oposición en la vía declarativa.

Por lo que respecta a la protección de los empresarios prestamistas, sostuvo que: "el mismo principio de equilibrio en las prestaciones que ha de presidir su interpretación, revela lo inadecuado de obligar a las entidades prestamistas, ante comportamientos de flagrante morosidad, a acudir en exclusiva a la vía declarativa para obtener la resolución contractual (art. 1124 CC), con cierre de la vía ejecutiva especial legalmente prevista y correlativa obstaculización de la efectividad de la garantía real".

Así pues, concluyó que: "[D]e ahí que no pueda afirmarse incondicionalmente que la decisión de proseguir la ejecución sea más perjudicial para el consumidor. Al contrario, sobreseer el procedimiento especial de ejecución para remitir a las partes al juicio declarativo, puede privar a todos los compradores de viviendas mediante préstamos hipotecarios a largo plazo anteriores a la Ley 1/2013 que contengan cláusulas abusivas de vencimiento anticipado de una regulación que contempla especiales ventajas, como las de liberación del bien y rehabilitación del contrato, en los términos expresados".

Ambas sentencias cuentan con el voto particular de Magistrado Francisco Javier Orduña Moreno quien sostiene que la doctrina jurisprudencial sentada en estas sentencias desnaturaliza el control de abusividad, su efectividad y su función. En particular, considera que los supuestos privilegios de la vía ejecutiva benefician únicamente a la entidad bancaria. Criterio que compartimos pues, lo único que desea un deudor cuando está siendo ejecutado, especialmente si el bien ejecutado es la vivienda habitual, es no ser desahuciado. La finalidad de la vía ejecutiva hipotecaria es única: permitir a los acreedores privilegiados obtener el resarcimiento por la vía más rápida posible. Esta inmediatez no se produce en el proceso declarativo y esta es la única y exclusiva razón por la que los deudores en estas circunstancias desean ir al declarativo y los acreedores rehúyen de él. Esta posibilidad que otorga el declarativo a los deudores insolventes de dilatar el máximo tiempo posible la pérdida de la vivienda habitual les concede la posibilidad de disponer de tiempo para trazar un plan de reestructuración económica y familiar para buscar una segunda oportunidad o fresh start. Ninguno de los beneficios que señalaba el TS lo son en realidad, ya que el consumidor que no puede afrontar una cuota del préstamo hipotecario a su vencimiento, en ningún escenario posible podrá liberar el bien pagando todas las cuotas impagadas, intereses y costas (693.3 LEC), teniendo además presente que podrá declararse en concurso tras la ejecución y quedar liberado de sus deudas (de cumplir con los requisitos 178 bis de la Ley Concursal). Por lo tanto, no hay ninguna ventaja creíble ni justificada para los consumidores en integrar la cláusula anulada.

43 Con todo, parece dudoso que se cumplan estos requisitos pues (i) no se declara cuál es esa norma supletoria por la que se sustituiría la cláusula anulada, pues el art. 693.2 LEC no es una norma de este tipo al exigir pacto específico de las partes; y (ii) la declaración de nulidad del vencimiento anticipado no comporta la nulidad del contrato.

AGÜERO ORTIZ, Alicia. La abusividad de las cláusulas de vencimiento anticipado en préstamos hipotecario. Revista Justicia y Derecho, Santiago, v. 1, n 1, 2018 
Estos pronunciamientos del TS han provocado una nueva oleada de cuestiones prejudiciales ${ }^{44}$, entre ellas la del propio Tribunal Supremo mencionada (auto de 8 de febrero de $2017^{45}$ ), quien plantea “ ¿Tiene facultades un tribunal nacional, conforme a la Directiva 93/13/CEE, para una vez declarada abusiva una cláusula de vencimiento anticipado de un contrato de préstamo o crédito con garantía hipotecaria poder valorar que la aplicación supletoria de una norma de Derecho nacional, aunque determine el inicio o la continuación del proceso de ejecución contra el consumidor, resulta más favorable para el mismo que sobreseer dicho proceso especial de ejecución hipotecaria y permitir al acreedor instar la resolución del contrato de préstamo o crédito, o la reclamación de las cantidades debidas, y la subsiguiente ejecución de la sentencia condenatoria, sin las ventajas que la ejecución especial hipotecaria reconoce al consumidor?".

Cabría esperar que el TJUE descartara esta posibilidad, en primer lugar, porque el artículo 693.2 LEC no constituye una norma supletoria en nuestro Derecho interno; y, en segundo lugar, porque la declaración de nulidad de la cláusula de vencimiento anticipado no comporta la nulidad del contrato. A mayor abundamiento, en el Auto de 17 de marzo de $2016^{46}$ comprendió que la expulsión del contrato de la cláusula de vencimiento anticipado no comportaba ninguna consecuencia negativa para el consumidor, no pareciendo dable su sustitución por una disposición de Derecho nacional, ya que: "interesa al consumidor que no se declare el vencimiento anticipado del reembolso del capital prestado".

Con todo, en aquel Auto no se tomaba en consideración los "beneficios" que la vía ejecutiva reporta al consumidor, apuntados por el Tribunal Supremo, por lo que es posible, aunque poco probable, que se produzca un cambio de criterio del Tribunal de Justicia de la Unión Europea.

\section{9. ¿Futuro de Cláusulas de Vencimiento anticipado?}

Con ocasión de la trasposición de la Directiva 2014/17/UE sobre los contratos de crédito celebrados con los consumidores para bienes inmuebles de uso residencial, el prelegislador español está trabajando en un Anteproyecto de Ley de Créditos Inmobiliarios ${ }^{47}$, cuyo artículo 15 introduce una nueva regla sobre el vencimiento anticipado en préstamos o créditos cuyo prestatario sea una persona física y que estén garantizados mediante hipoteca sobre vivienda o cuya finalidad sea la adquisición de bienes inmuebles para uso residencial. En concreto, se establece como norma imperativa, que no aceptará pacto en contrario, que el vencimiento anticipado se produzca si: (i) el incumplimiento representa un 3\% del valor del préstamo, en caso de que éste se produzca en los diez primeros años de vida del préstamo, o en cualquier momento si el plazo de amortización fuera inferior a diez años; o (ii) el incumplimiento representa un $5 \%$ del valor del préstamo si el incumplimiento se produce tras los diez primeros años. Esta norma impone a los acreedores la tolerancia de incumplimientos mayores a los previstos en el actual art. 693 LEC (incumplimiento equivalente a tres mensualidades) ${ }^{48}$.

44 Véase las cuestiones prejudiciales planteadas por el JPI no 1 de Fuenlabrada mediante Auto de 8 febrero 2016 (JUR 2016\44812) y por el JPI no 2 de Santander mediante Auto de 8 marzo 2016 (JUR 2016\54641).

45 RJ $2017 \backslash 365$.

46 TJCE 2016\121

47 Disponible en: http://www.rdmf.es/wp-content/uploads/2017/04/anteproyecto-de-ley-reguladora-de-los-contratos-de-crdito-inmobiliario.pdf

48 A modo de ilustración, tomemos por caso un préstamo hipotecario de $200.000 €$ a interés fijo del 1,5\% y a 30 años (la cuota mensual sería de 690€). En aplicación del criterio del actual art. 693 LEC el acreedor podría vencer anticipadamente por el impago de 2.070€. Por el contrario, de conformidad con el art. $15 \mathrm{APLCl}$ podría vencer en los diez primeros años por un incumplimiento de 6.000€; o de $10.000 €$ tras los diez primeros años.

AGÜERO ORTIZ, Alicia. La abusividad de las cláusulas de vencimiento anticipado en préstamos hipotecario. Revista Justicia y Derecho, Santiago, v. 1, n 1, 2018 
En cualquier caso, dicho precepto constituye un puerto seguro para las entidades prestamistas, pues como expone la propia exposición de motivos de la norma, la configuración de esta norma como norma imperativa tiene por "objeto de impedir la existencia de cláusulas abusivas y garantizar el necesario equilibrio económico y financiero entre las partes". En otras palabras, esta regulación del vencimiento anticipado caería dentro del ámbito de aplicación del principio de adecuación del art. 1.2 Directiva 93/13/CEE, estando excluida del control de abusividad.

\section{Conclusiones}

Las discrepancias judiciales en torno a la cláusula de vencimiento anticipado han creado una insostenible inseguridad jurídica. La STJUE de 26.1.2017 $7^{49}$ era esperada como agua de mayo por todos los círculos afectados, pues se esperaba que resolviera si las cláusulas de vencimiento anticipado que se limitaran a reproducir el artículo 693.2 LEC quedaban excluidas del ámbito de aplicación de la Directiva 93/13/CEE; y si declarada abusiva la cláusula, debía entenderse cerrada la puerta al proceso de ejecución hipotecaria. Con todo, el TJUE no aclara en la sentencia comentada dichas cuestiones, en gran medida porque no fueron óptimamente planteadas por el órgano consultante. Aun así, la sentencia sí ha contribuido a clarificar algunos aspectos relevantes para el ordenamiento jurídico español, en concreto, que el control de abusividad debe realizarse en abstracto y no en atención a la ejecución que el predisponte realice de las cláusulas contractuales; y que el artículo 693 LEC no constituye un criterio de abusividad de las cláusulas de vencimiento anticipado, sino sólo de legalidad. Por lo demás, debemos esperar a un próximo pronunciamiento del TJUE que resuelva si resulta de aplicación la "blue pencil rule", esto es, si puede declararse la abusividad la parte de la cláusula que resulte abusiva pero mantenerse la validez del resto de la cláusula; y si, tal y como comprende nuestro TS, declarada abusiva la cláusula de vencimiento anticipado debe proseguirse la ejecución por ser dicho proceso más beneficioso para el consumidor.

Finalmente, el Anteproyecto de Ley de Créditos Inmobiliarios aportará seguridad jurídica al establecer una norma clara y homogénea de vencimiento anticipado. Ahora bien, el hecho de que se extraiga la norma del control de abusividad puede resultar peligroso, pues no se ha justificado que la norma prevista satisfaga los criterios de validez de las cláusulas de vencimiento anticipado establecidas por el TJUE.

\section{Bibliografía Citada}

Adan Domenech, Fredric (2016): "Tribunal Supremo versus Tribunal Superior de Justicia. Aplicación jurisprudencial de las cláusulas de vencimiento anticipado", Revista de Derecho vLex - Núm. 143, Abril 2016. VLEX-632460969. Disponible en: https://app.vlex.com/\#vid/tribunal-supremo-versus-tribunal-632460969 [fecha última consulta: 30.10.2017].

Carrasco Perera, Ángel (2015): "Ejecución hipotecaria instada sobre la base de una cláusula de vencimiento anticipado que se reputa abusiva, o cada día un poco más cerca del abismo", Análisis GA\&P, Vol. Diciembre, 2015. Disponible en: http://www.gomezacebo-pombo.com/media/k2/attachments/ejecucion-hipotecaria-instada-sobre-la-base-de-una-clausula-de-vencimiento-anticipado-que-se-reputa-abusiva-o-cada-dia-un-poco-mas-cerca-del-abismo.pdf [fecha última consulta: 30.10.2017].

49 JUR 2017\26895.

AGÜERO ORTIZ, Alicia. La abusividad de las cláusulas de vencimiento anticipado en préstamos hipotecario. Revista Justicia y Derecho, Santiago, v. 1, n 1, 2018 
Carrasco Perera, Ángel (2012): "Las cláusulas abusivas se eliminan, sin más: no cabe reducirlas, moderarlas ni modificarlas", Revista CESCO de Derecho de Consumo, Vol. 3, pp. 145-147.

Fernández Seijo, José María; Sanjuán y Muñoz, Enrique; Antón Guijarro, Javier; Hernández Rodríguez, María del Mar (2016): “¿Cuáles son los efectos de la nulidad de la cláusula de vencimiento anticipado inserta en contratos de préstamo hipotecario suscrito con consumidores? En concreto, ¿la nulidad de la cláusula impide acudir al procedimiento de ejecución hipotecaria?", Revista Consumo y Empresa, Vol. 1. Disponible en: http://vlex.com/vid/cuales-efectos-nulidad-clausula-594142131 [fecha última consulta: 30.10.2017].

Giménez Alcover, Pepe (2016): "La cláusula de vencimiento anticipado y el principio de presunción de adecuación", Revista de Derecho vLex, Vol. 143. Disponible en: http://vlex.com/vid/clausula-vencimiento-anticipado-principio-632337681 [fecha última consulta: 30.10.2017].

MARTín FABA, José María (2016): “Se ha estabilizado en las AAPP la doctrina en materia de abusividad de las cláusulas de vencimiento anticipado en préstamos hipotecarios derivada de las SSTS de 23 de diciembre de 2015 y 18 de febrero de 2016?", Revista CESCO de Derecho de Consumo, Vol. 19, pp. 112-132.

Martín Faba, José María (2017): "Una buena tesis sobre la validez de la cláusula de vencimiento anticipado", Revista CESCO de Derecho de Consumo, n²2/2017. Disponible en: https://revista.uclm.es/index.php/cesco/article/view/1437/1201 [fecha última consulta: 30.10.2017].

Martínez Espín, Pascual (2017): "Una nueva cuestión prejudicial: abusividad de la cláusula intereses de demora y sus efectos", Centro de Estudios de Consumo (CESCO). Disponible en: http://blog.uclm.es/ cesco/files/2017/03/Una-nueva-cuestion-prejudicial-abusividad-de-la-clausula-intereses-de-demora-y-sus-efectos.pdf [fecha última consulta: 30.10.2017].

Puyalto Franco, María José (2007): Las cláusulas de vencimiento anticipado en los préstamos bancarios al consumo (Madrid, Dykinson).

\section{NORMAS CITADAS}

Código Civil, Real Decreto de 24 de julio de 1889 por el que se publica el Código Civil.

Ley HipoteCARIA, Decreto de 8 de febrero de 1946, por el que se aprueba la nueva redacción oficial de la Ley Hipotecaria.

Ley HipoteCARIA, de 16 de diciembre de 1909.

LEY 1/2000, de 7 de enero, de Enjuiciamiento Civil.

DiReCtIva 93/13/CEE del Consejo, de 5 de abril de 1993, sobre las cláusulas abusivas en los contratos celebrados con consumidores.

Real Decreto Legislativo 1/2007, de 16 de noviembre, por el que se aprueba el texto refundido de la Ley General para la Defensa de los Consumidores y Usuarios y otras leyes complementarias.

LEY 1/2013, de 14 de mayo, de medidas para reforzar la protección a los deudores hipotecarios, reestructuración de deuda y alquiler social.

Ley 22/2003, de 9 de julio, Concursal.

LEY HiPOTECARIA PARA LAS PROVINCIAS DE ULTRAMAR, de 14 de julio de 1893.

AGÜERO ORTIZ, Alicia. La abusividad de las cláusulas de vencimiento anticipado en préstamos hipotecario. Revista Justicia y Derecho, Santiago, v. 1, no 1, 2018 
Directiva 2014/17/UE del Parlamento Europeo y del Consejo, de 4 de febrero de 2014, sobre los contratos de crédito celebrados con los consumidores para bienes inmuebles de uso residencial y por la que se modifican las Directivas 2008/48/CE y 2013/36/UE y el Reglamento (UE) no 1093/2010.

\section{JURISPRUDENCIA CITADA}

Sentencia del Tribunal de Justicia de la Unión Europea de 14 de junio de 2012 (Asunto C618/10).

Sentencia del Tribunal de Justicia de la Unión Europea de 14 de marzo de 2013 (Asunto C415/11).

Auto del Tribunal de Justicia de la Unión Europea de 14 de noviembre de 2013, Banco Popular Español y Banco de Valencia, asuntos acumulados (Asunto C-537/12 y C-116/13).

Sentencia del Tribunal de Justicia de la Unión Europea de 30 abril de 2014, Caso Barclays Bank, S.A., (Asunto $(-280 / 13)$.

Sentencia del Tribunal de Justicia de la Unión Europea de 14 de marzo de 2013, Caso Mohamed Aziz contra Catalunya Caixa (Asunto C-415/11)

Auto del Tribunal de Justicia de la Unión Europea de 11 de junio de 2015 (Asunto C602/13).

Auto del Tribunal de Justicia de la Unión Europea de 8 de julio de 2015 (Asunto C90/14).

Auto del Tribunal de Justicia de la Unión Europea TJUE de 17 marzo 2016 (Asunto C613/15).

Sentencia del Tribunal de Justicia de la Unión Europea de 26 de enero de 2017 (Asunto C-421/14).

Sentencia del Tribunal Supremo de 4 de junio de 2008 (RJ 2008\3196).

Sentencia del Tribunal Supremo de 12 de diciembre de 2008 (RJ 2009\152).

Sentencia del Tribunal Supremo de 16 de diciembre de 2009 (RJ 2010\702).

Sentencia del Tribunal Supremo de 17 de febrero de 2011 (RJ 2011\3316).

Sentencia del Tribunal Supremo de 23 de diciembre de 2015 (RJ 2015\5714).

Sentencia del Tribunal Supremo de 18 de febrero de 2016 (RJ 2016\619).

Auto del Tribunal Supremo de 22 de febrero de 2017 (RJ 2017\597).

Auto de la Audiencia Provincial de Sevilla de 30 junio 2015 (JUR\2015\209046).

Auto de la Audiencia Provincial de Madrid 17 diciembre 2014 (AC\2014\2289).

Auto de la Audiencia Provincial de Madrid de 2 marzo de 2015 (AC\2015\354).

Auto de la Audiencia Provincial de Madrid de 4 mayo 2015 (JUR\2015\150125).

Auto de la Audiencia Provincial de Madrid de 29 de junio de 2016 (JUR 2016\184356).

Auto de la Audiencia Provincial de Córdoba de 13 noviembre 2014 (AC\2014\2119).

Auto de la Audiencia Provincial de Córdoba de 27 enero 2015 (AC\2015\595).

Auto de la Audiencia Provincial de Barcelona de 16 febrero 2014 (AC\2015\433).

Auto de la Audiencia Provincial de Barcelona de 7 abril 2017 (AC\2015\982).

AGÜERO ORTIZ, Alicia. La abusividad de las cláusulas de vencimiento anticipado en préstamos hipotecario. Revista Justicia y Derecho, Santiago, v. 1, n 1, 2018 
Auto de la Audiencia Provincial de Girona de 30 enero 2015 (JUR\2015\116900).

Auto de la Audiencia Provincial de Girona de 10 diciembre 2015 (JUR\2015\56489).

Auto de la Audiencia Provincial Cádiz de 24 octubre 2015 (AC\2015\215).

Auto de la Audiencia Provincial de Cádiz de 28 noviembre 2015 (AC\2015\241).

Auto de la Audiencia Provincial de Valencia de 10 febrero 2014 (AC\2014\487).

Auto de la Audiencia Provincial de Valencia de 17 abril 2015 (AC\2015\989).

Auto de la Audiencia Provincial de Valencia de 25 junio 2014 (AC\2014\1792).

Auto de la Audiencia Provincial de Valencia de 17 octubre 2014 (AC\2014\1998).

Auto de la Audiencia Provincial de Valencia de 30 diciembre 2014 (AC\2014\415).

Auto de la Audiencia Provincial de Valencia de 16 marzo 2015 (JUR\2015\126187).

Sentencia de la Audiencia Provincial de Murcia de 16 diciembre 2015 (JUR\2015\50861).

Auto de la Audiencia Provincial de Pontevedra de 10 febrero 2014 (AC\2014\487).

Auto del Juzgado de Primera Instancia (n 1) de Fuenlabrada de 8 febrero 2016 (JUR 2016\44812).

Auto del Juzgado de Primera Instancia (n²) de Santander de 8 marzo 2016 (JUR 2016\54641).

Acuerdo del Pleno Jurisdiccional de las Secciones Civiles de la Audiencia Provincial de Sevilla de 23 de marzo de 2017 (AC\2017\438). 